\title{
NOVA VARSÓVIA, LABORATÓRIO DE OCUPAÇÃO OU NINHO DE TERRORISTAS?: A Faixa de Gaza e a vida nua
}

\author{
Fábio Bacila Sahd*
}

\section{Resumo}

A partir de 2005, quando o governo israelense retirou seus colonos e militares da Faixa de Gaza, o território palestino foi cada vez mais isolado e cercado e seus habitantes submetidos a punições coletivas e a morte violenta. A política securitária de Israel em relação à Faixa, adotada oficialmente para coibir o terrorismo palestino, tem culminado em um longo sofrimento para a população local como um todo, que vê suas condições de vida se deteriorarem com uma privação generalizada de serviços e bens básicos. Destituindo-se do discurso oficial simplificador da guerra contra o terror, nesse contexto no qual a violência foi ainda mais banalizada, busca-se analisar a pertinência de considerar Gaza pelos conceitos que pensam a política na modernidade, como imunitas, campo e homo sacer. O artigo apresenta sucintamente esses conceitos verificando, com base em testemunhos e relatórios de organizações não governamentais, sua contribuição à compreensão do caso específico.

Palavras-chave: Territórios Palestinos Ocupados. Cultura da Impunidade. Israel. Homo sacer. Desengajamento Unilateral.

O oficial superior ex-Hagana Yisca Shadmi foi considerado culpado de assassinar dois prisioneiros palestinos. Ele é um nome familiar na história dos palestinos em Israel: em outubro de 1956 Shadmi foi um dos principais perpetradores do massacre de Kfar Qassim, no qual quarenta e nove palestinos perderam suas vidas. Ele escapou da punição por ter parte no massacre, e prosseguiu até se tornar um alto oficial no aparato de governo que controlava a relação do Estado com sua minoria palestina. Ele foi absolvido, eventualmente, em 1958. Seu caso revela duas características do tratamento israelense em relação aos cidadãos palestinos que continua até os dias de hoje: a primeira é que as pessoas indiciadas por crimes contra os árabes estão aptas a permanecerem em posições nas quais continuam a afetar

\footnotetext{
* Mestre em História pela Universidade Estadual de Maringá. Autor do livro “Oriente Médio desmistificado: fundamentalismo, terrorismo e barbárie”. E-mail: fabiobacila@hotmail.com
} 
as vidas dos palestinos e, segundo, elas, nunca serão levadas à justiça (PAPPE, 2006, p. 202. Tradução livre do autor).

\section{Introdução}

O embate na Palestina/Israel já dura mais de um século. Desde os primeiros atritos envolvendo árabes autóctones (palestinos) e imigrantes judeus até hoje a situação passou por intensas mudanças. Embora seu caráter central tenha se mantido - um choque de nacionalismos e de visões opostas sobre a natureza do mesmo território -, evoluções significativas tiveram lugar, destacando-se os anos de 1948 e 1967. Primeiro, veio a fundação do Estado de Israel em uma parte do mandato britânico da Palestina. Tal iniciativa desaguou em uma guerra aberta com os países vizinhos, que por sua vez trouxe consequências demográficas profundas (o deslocamento de mais de quinhentos mil nativos, inaugurando-se aí o problema dos refugiados palestinos). Dezenove anos depois, com a Guerra dos Seis Dias, o já consolidado Estado israelense passou a ocupar a totalidade do território.

Assim, o conflito evoluiu de um embate étnico envolvendo duas populações submetidas a um mesmo governo imperial para a constituição e monopolização de aparatos estatais por um dos grupos - judaico -, que passou a os utilizar para consolidar seus interesses comunitários em detrimento do outro. Destarte, ao final de 1967, os palestinos, outrora o grupo majoritário que disputava a soberania com a mandatária e com a minoria judaica, estavam divididos entre aqueles que permaneceram em Israel e se tornaram cidadãos, os exilados de 1948 e os residentes dos territórios recém-ocupados e gradativamente colonizados. A fragilidade da vida se tornou uma característica marcante aos residentes desses territórios, submetidos ao controle de um Estado que lhes é hostil, pois não tem a intenção de integrá-los, mas sim de judaizar o espaço (YIFTACHEL, 2006).

Conforme Neve Gordon (2008, p. 49-55), para manter os habitantes de Gaza e da Cisjordânia submissos ao mesmo tempo que consolidava a ocupação e a colonização desses territórios, Israel se utilizou de duas estratégias distintas. Até aproximadamente o início da Primeira Intifada (1987), buscou estabilizar seu domínio por meio de medidas disciplinares, ocultando os meios coercitivos mais explícitos sem abrir mão das formas de controle voltadas à administração do cotidiano dos palestinos. O plano era normalizar a ocupação tentando fazer coincidir os interesses de ocupantes e ocupados, enquanto os últimos tinham suas vidas controladas e seus recursos explorados (terra, água e trabalho). Ainda que o caminho idealizado fosse "sem presença, sem interferência e pontes abertas", na prática, paralelamente 
aos mecanismos invisíveis e permanentes de controle, a coerção violenta também foi exercida para suprimir manifestações de resistência. A constante recorrência à força culminou no gradual desmascaramento e no enfraquecimento da política de “ocupação invisível”, visto que seu sucesso dependia da ocultação de seus aparatos.

Então, a partir da deflagração da Primeira Intifada, Israel mudou a estratégia da ocupação, baseando-a na segregação das populações e no uso aberto da coação e da repressão para suprimir a oposição. A violência desde então atingiu patamares não antes vistos, partindo tanto das forças ocupantes quanto de resistência, sendo o paroxismo a Segunda Intifada. Esta, vinculada à expansão das colônias na Cisjordânia, desgastou o processo de paz iniciado em meados dos anos 1990 e tornou o conflito ainda mais sangrento e radicalizado, reafirmando seu caráter étnico. Com o sepultamento dos acordos de Oslo, aumentou o consenso intragrupal de "judeus israelenses” e palestinos e houve uma rigidificação das fronteiras étnicas e deterioração das relações recíprocas, acompanhadas de um crescente número de discursos e leis racistas em Israel (KLEIN, 2010; NAFFA, 2009). Conforme Roberto Ramirez (2010) e Gideon Levy (2010), se a Primeira Intifada dividiu a sociedade israelense, os ataques conduzidos por facções guerrilheiras palestinas no novo milênio tiveram como efeito sua unificação e uma guinada para a direita.

É nesse contexto que emergiu a política israelense de isolar completamente Gaza, cuja implementação se deu em paralelo à crise dos acordos de Oslo e à ascensão do Movimento de Resistência Islâmica (Hamas). A vitória eleitoral do Hamas, em janeiro de 2006 - quando a Autoridade Palestina estava desacreditada aos olhos da população local, que a acusava de brutalidade, corrupção e conivência com o ocupante -, legitimou o encerramento de Gaza, dado que outros países (como os Estados Unidos) passaram a apoiar o bloqueio e o boicote, pois não reconhecem o grupo palestino e o classificam como uma organização "terrorista”. Portanto, desde a retirada dos colonos e das tropas israelenses (desengajamento unilateral ${ }^{1}$ ) e a ascensão do Hamas a Faixa foi ainda mais isolada e a violência difundida ${ }^{2}$. Ao passo que

\footnotetext{
${ }^{1}$ Vários pesquisadores criticaram imediatamente a alegação oficial, que definiu o "desengajamento unilateral" como um avanço para a paz dado que terminava a "ocupação" e a responsabilidade do "Estado judeu” sobre os palestinos. Embora a ação tenha findado com a presença israelense permanente, iniciada em 1967, para esses críticos seu real significado foi apenas uma mudança na forma de controle exercida sobre a região e uma tentativa de reduzir os custos e as fricções para aprimorar e acelerar a colonização da Cisjordânia (ROY, 2005, 2009; ARONSON, 2005; LEVY, 2010). Nessa mesma linha, OrenYiftachel (2006, p. 82) afirma que o desengajamento não foi o prenúncio de uma descolonização geral, mas apenas um ajustamento na estratégia de judaização da Palestina/Israel.

${ }^{2}$ Após a vitória eleitoral em janeiro de 2006, as divergências e tensões entre militantes do Hamas e do Fatah em Gaza foram progressivamente se agravando, até chegar ao ápice em meados de 2007, quando se multiplicaram os confrontos armados, que então culminaram na tomada do poder pelo primeiro. Na versão oficial israelense, o Hamas deu um golpe de Estado premeditado e assumiu todos os aparatos políticos da Faixa, o que justificou sua
} 
ocorria a evacuação, era reforçada a barreira de segurança no seu entorno, com diferentes meios eletrônicos como dispositivos e metralhadoras acionadas a distância. Tão logo os últimos colonos partiram, Gaza foi declarada fronteira internacional e demolições tiveram lugar, ampliando a “zona tampão” na fronteira. Apesar da retirada formal, Israel continuou a controlar sistematicamente o território, executando operações militares, vigiando e administrando o espaço aéreo, terrestre e marítimo, restringindo o fluxo de pessoas e mercadorias, bem como o acesso a serviços e recursos básicos. Para Ilan Pappé (2009),

a presença dos colonos, contudo, dificultava para as forças israelenses retaliarem [os mísseis caseiros] com a brutalidade que eles utilizam contra alvos puramente palestinos. Então os colonos foram removidos, não como parte de um processo de paz unilateral, como muitos arguiram no momento (ao ponto de sugerir que Ariel Sharon fosse agraciado com o Nobel da paz), mas para facilitar qualquer ação militar subsequente contra a Faixa de Gaza e para consolidar o controle da Cisjordânia (Tradução livre do autor).

Darryl Li (2006) interpreta a situação da Faixa pós-desengajamento como um "laboratório da ocupação”, onde Israel testa e refina várias técnicas buscando conciliar "máximo controle” com "mínima responsabilidade” por meio de um controle a distância. Ou seja, apesar da retirada, a Faixa permaneceu um território ocupado e sua população foi efetivamente encerrada. Desde então, a violência atingiu novos patamares, alimentada por um fechamento hermético do território - inclusive com o impedimento da entrada de produtos como brinquedos, remédios, chocolates e temperos - por um processo de paz falho, que perpetua e acentua a ocupação da Cisjordânia (ARURI, 2006); e por constantes bombardeios e assassinatos extrajudiciais, que provocam revides com mísseis da resistência palestina (SIEFFERT, 2009, p. 68-70). Também em relação à Gaza, Israel mantém o controle da escalada da violência e reforça seu poder de dissuasão com ataques intensos, mas pontuais, elementos estes que, segundo Zeev Maoz (2006) fundamentam sua estratégia securitária desde os primórdios da fundação do país.

Nesse contexto, entre 2005 e dezembro de 2008, enquanto os foguetes da resistência mataram onze israelenses, as forças deste Estado mataram cerca de mil duzentos e cinquenta palestinos de Gaza, incluindo duzentas e vinte e duas crianças (FINKELSTEIN, 2010, p. 26). Deste total, conforme três relatórios anuais da ONG B'Tselem, pelo menos quinhentos e dezoito não se envolveram nas hostilidades. No período, com base na alegação de que Israel

denominação como “território hostil” e seu maior isolamento. Sieffert (2009), citando Mohamed al-Rantissi, menciona a possibilidade da tomada do poder pelo Hamas ser uma ação preventiva contra uma tentativa golpista do Fatah, dado a proliferação de seus armamentos - interpretada como apoio de Israel e dos EUA. 
estava envolvido em um conflito armado, praticamente cessaram as ordens para que sua polícia militar investigasse os casos nos quais civis palestinos foram mortos (B'TSELEM, 2007, p. 8-9). O paroxismo da violência e da impunidade sistemática ocorreu entre dezembro de 2008 e janeiro de 2009, quando, em decorrência da operação Chumbo Fundido e em apenas três semanas, morreram em Gaza cerca de mil e quatrocentas pessoas - sendo a maior parte de civis -, foram feridas mais de cinco mil e trezentas e milhares ficaram desabrigados. Citando um trecho do Relatório Goldstone ${ }^{3}$,

o que ocorreu em apenas pouco mais de três semanas no final de 2008 e começo de 2009 foi um ataque deliberadamente desproporcional designado para punir, humilhar e aterrorizar a população civil, radicalmente debilitando sua capacidade econômica [...] A Missão também conclui que as forças armadas de Israel ilegalmente e ostentosamente atacaram e destruíram sem necessidade militar um número de objetos e instalações de produções ou processadores de comida (incluindo moinhos, terra e estufas), instalações de água potável, fazendas e animais, em violação ao principio da indistinção. A partir dos fatos investigados, a Missão conclui que essa destruição foi perpetrada com o propósito de negar meios de subsistência à população civil (UN FACT FINDING MISSION, 2009, p. 408; 415-416. Tradução livre do autor).

Teoricamente, as transformações mais recentes do conflito podem ser compreendidas com base no conceito de imunitas que, segundo Roberto Esposito, caracteriza a experiência política moderna de uma forma geral. Conforme o autor, uma exacerbada "possibilidade contagiosa” ou uma ameaça de ruptura de um equilíbrio anterior em uma sociedade - "perigo demográfico" ou "terrorismo" - outorga especial importância à exigência de imunização, culminando em um fechamento e exclusão do outro. Ao mesmo tempo em que determinado tipo de vida é protegido outro é negado, neutralizando a suposta contaminação que pode gerar (2005, p. 9-19). A comunidade enfatiza seus caracteres identitários coletivos vistos como puros e autênticos, "essencializa” sua existência e cria mecanismos de controle da circulação e do contato que excluem o diferente (2003, p. 44-45).

Seguindo a análise de Esposito e de outros autores que pensam a fragilidade da vida diante dos sistemas de poder atuais de uma forma mais ampla, não se propõe aqui analisar o

\footnotetext{
${ }^{3}$ Diante das diversas denúncias de violações aos direitos humanos e humanitários internacionais durante a operação Chumbo Fundido, a ONU prescreveu a formação de uma equipe internacional para investigar os fatos. Em setembro de 2009 o grupo encabeçado pelo juiz Richard Goldstone publicou seu relatório, que ficou conhecido como Relatório Goldstein, que contém severas críticas à conduta adotada pelas forças israelenses e palestinas durante as hostilidades. Ele menciona, inclusive, a possibilidade de Israel ter cometido crimes contra a humanidade. Declarações de seu redator geraram muita polêmica, sendo veiculadas notícias que ele teria invalidado o documento, quando disse que mudaria alguns pontos se o estivesse escrito depois. De qualquer forma, o relatório da comissão compila informações de diversos outros documentos, publicados por organizações convictas de suas conclusões.
} 
controle exercido a distância e as operações militares israelenses em Gaza como um caso isolado, específico, distinto de experiências coevas. A discriminação do Estado judeu entre palestinos e israelenses, entre aqueles que fazem parte do corpo da nação e aqueles que estão fora, que constituem seu outro, é inserida no quadro maior da política na modernidade, no qual, a opressão prática de povos sobre povos e classes sobre classes contravém as afirmações legais internacionais dos direitos de todos os seres humanos à igualdade, autonomia e soberania.

Em outras palavras, também os palestinos integram um novo sistema de poder (modernidade), caracterizado por ambições de engenharia social da parte de Estados territoriais “jardineiros”, que passaram a gerir a própria vida, a vida biológica, podendo a extinguir ou perpetuar conforme os interesses dos grupos que controlam seus aparatos. A violência, que perpassa os projetos de tornar a sociedade “objeto de planejamento, cultivo e extirpação de ervas daninhas”, ao invés de ser erradicada foi reutilizada e redistribuída em territórios segregados e isolados, “áreas de sombra crepusculares”, inacessíveis aos membros comuns - como se tornou Gaza, completamente sitiada após a retirada dos colonos e militares israelenses, em 2005 (BAUMAN, 1998). Grupos inteiros são assim excluídos do sistema legal, ficando expostos à exceção. Giorgio Agamben (2007) define os últimos como homo sacer, que são pessoas desprotegidas e matáveis, cuja vida pode ser retirada sem que se cometa uma contravenção. Paralelamente, são criados e mantidos os campos, locais que materializam de forma permanente o estado de exceção e concentram os extermináveis.

A consolidação da modernidade como um novo sistema de poder (FEIERSTEIN, 2011) trouxe problemas inéditos, como os limites impostos pelos próprios paradigmas que a embasaram: a autonomia, a igualdade e a soberania. Se tais princípios fundamentaram a constituição de regimes legitimados pela vontade soberana do povo, eles também tiveram que ser constantemente subvertidos, visto as discrepâncias entre teoria e prática. É o caso do direito à liberdade, conquanto os interesses materiais das elites não sejam ameaçados, e da igualdade formal entre as pessoas, contraposta à desigualdade necessária para justificar a submissão de povos e sua colonização sobre a bandeira do racismo. Ou seja, se os valores da autonomia, soberania e igualdade possibilitaram uma análise idealizada que legitimou a modernidade, na pratica a continuidade da dominação de alguns grupos sobre outros exigiu a subversão de tais elementos, o que acarretou em problemas de consenso, racionalidade e legitimidade do próprio sistema (FEIERSTEIN, 2011). Assim como os diversos golpes militares ocorridos na América Latina na segunda metade do século XX, a vitória eleitoral do Hamas evidencia bem os limites práticos dentro dos quais a soberania e a liberdade de escolha 
dos povos podem ser exercidas. Se transcendidas determinadas linhas vermelhas, logo a regra e a lei dão lugar à exceção e os direitos são suspensos.

Portanto, cabe reiterar, o objeto do presente artigo - a atual política securitária israelense em relação à Gaza e a morte não punível de civis - se insere em um recorte temporal e espacial mais amplo no qual, segundo Eric Hobsbawm (1998), houve um "avanço generalizado da barbárie”. As guerras civilizadas perderam espaço para as "guerras religiosas”, caracterizadas pelo não discernimento entre civis e militares e pela necessidade de demonização dos inimigos para mobilizar as sociedades democráticas. Assim, a supressão dos direitos fundamentais foi justificada e a "barbarização” facilitada. Jean-Luc Nancy (2003, p. 10-12) afirma que o século XX - e por que não o XXI? - se caracteriza por uma recordação que de tão agoniante se tornou inevitável: “em nome da comunidade a humanidade colocou a prova uma capacidade insuspeitável de autodestruição, tanto na quantidade quando na ideia e no valor”. “Obras de morte” foram e ainda são levadas a cabo em nome de essências comunitárias, baseadas em elementos como sangue, etnia, raça, religião e classe.

Pensando nessas “obras de morte” ou extermínios contemporâneos, Zygmunt Bauman sublinha que, ao invés de marcarem um retrocesso no avanço civilizacional são compostas por combinações específicas de causas comuns e banais, possibilidades inerentes ao "processo civilizador”. Os processos ideativos que por sua própria lógica podem levar a projetos genocidas e os recursos técnicos que permitem a efetivação destes "não apenas se revelaram plenamente compatíveis com a civilização moderna, como foram condicionados, criados e fornecidos por ela” (BAUMAN, 1998, p. 110-111). Eugène Enriquez (2001) também destaca essa presença da barbárie na modernidade, defendendo que, ao longo do século XX foi conferido um princípio de legitimidade ao domínio do assassinato em massa. A violência "total” contra o outro foi em partes motivada pelos desejos utópicos de construção de “cidades perfeitas”, que apresentam uma faceta atroz em sua promessa de realizar uma espécie de paraíso perdido na terra. Essa dinâmica entre utopia e barbárie fica clara na relação do "Estado judeu" e do sionismo com os palestinos. O anseio de outrora pela criação e de agora pela manutenção de um Estado étnico gera a violência contra o outro - palestino -, que “contagia” e ameaça sua sobrevivência como entidade assumidamente étnica.

Em suma, contrariamente às perspectivas que defendem a existência de um suposto progresso geral da civilização e da humanidade e veem em eventos como o Holocausto uma exceção a essa marcha irrefreável, autores como Michel Foucault, Bauman, Nancy, Esposito, Agamben e Feierstein se debruçam sobre a faceta sombria dos novos tempos, buscando compreender as relações de poder estabelecidas nesse período que testemunhou os maiores 
extermínios em massa da história. O que se busca aqui é justamente olhar para o conjunto dos acontecimentos na Palestina/Israel por meio desse prisma obscuro, mas real, e não como uma exceção atual, um conflito causado pela degenerescência de alguns que insistem em se apegar a valores retrógrados e bárbaros. Partindo dessa perspectiva, como parte de um sistema de poder mais amplo a situação na Faixa de Gaza apresenta paralelos com outras experiências contemporâneas, nas quais Estados “jardineiros” implementam soluções variadas para lidar com minorias não integráveis, iguais na teoria, mas desiguais na prática, com direitos reconhecidos à soberania e autodeterminação, mas controladas, submetidas e expostas à exceção.

Ou seja, o fulcro do presente artigo é relacionar a política israelense diante da população de Gaza com as características mais gerais da modernidade como sistema de poder, mais especificamente considerar o território e seus habitantes com base nas duas categorias trabalhadas por Agamben, o homo sacer e o campo. Essa abordagem se fundamenta nas mortes ali ocasionadas pelo "ocupante a distância” (LI, 2006) e nas explícitas contradições existentes entre os documentos oficiais produzidos por Israel e os relatórios publicados por organizações não governamentais e por entidades internacionais, que denunciam certa “cultura da impunidade” e a parcialidade das investigações conduzidas pelo ocupante.

Parte-se aqui da conclusão defendida pela ONG israelense Gisha (2007) de que quando as ações do ocupante resultaram no ferimento ou na morte exclusiva de civis, ou ainda destruíram suas propriedades, elas ou não foram investigadas ou o foram de forma parcial.

\section{O Hamas e o discurso oficial israelense}

O site do Ministério de Relações Exteriores de Israel (ISRAELI MINISTER OF FOREING AFFAIRS, 2012) e comunicados oficiais veiculam uma representação caricatural do Movimento de Resistência Islâmico (Hamas), como a quintessência do terrorismo jihadista “inimigo da paz”. O primeiro define o Hamas como uma "organização terrorista impenitente, apoiada pelo Irã e dedicada à destruição de Israel”, que tem como método a jihad. O Movimento, além de supostamente nutrir um discurso do ódio irracional, é responsabilizado por ataques suicidas e com armas convencionais contra civis israelenses, que sem motivos teriam se tornado ainda mais comuns após o desengajamento, em 2005. Dois anos depois, o Hamas “assumiu brutalmente o controle de Gaza, transformando a Faixa em um território islamista radical a partir do qual ele continua a atacar civis israelenses com morteiros e mísseis”. A “força terrorista” matou centenas de civis israelenses, e "continua a se armar para 
perpetrar um terrorismo ainda mais mortífero”. O Movimento não teria aceitado três mínimas condições da comunidade internacional para ser reconhecido, e nem mesmo dado sinais que estaria em algum momento predisposto a: "renunciar o terrorismo", reconhecer o direito do Estado de Israel à existência e os tratados anteriores firmados entre "os palestinos” (como se seus membros não o fossem) e Israel. Ademais, contaria com o apoio constante da Síria e do Irã no suprimento de armas tecnologicamente avançadas, ajuda logística, instrução, treinamento, transferência de fundos e suporte propagandístico. Em suma, a Faixa considerada pelo governo israelense como "território hostil” em 2007 - seria um "ninho de terroristas” (LEVY, 2004).

Denis Sieffert (2010, p. 40-42), jornalista francês autor de um livro sobre a "guerra midiática israelense”, defende que o intento das ações do Hamas é sempre distorcido e quase nunca se menciona que não foi ele que iniciou o conflito. Apesar de ser um movimento de resistência fundado em 1987 contra a ocupação e como consequência de um “conflito de natureza colonial” é supostamente o agressor. Outro elemento ausente das narrativas oficiais é que, não fosse pelo sentimento difundido entre os palestinos de terem sido lesados pelos acordos de Oslo - que não culminaram em seu Estado e nem no final da ocupação possivelmente o Movimento não teria ganhado as proporções que tomou. Logo se oculta que ele seja uma resistência política e social baseada na religião e no nacionalismo contra a política colonial, o projeto de judaização e a estrutura etnocrática de Israel.

Ainda segundo Sieffert, outros mitos que fundamentam o discurso da grande mídia sobre o Hamas é o suposto fanatismo e o analfabetismo de seus apoiadores e a luta global que pretensamente trava contra todos os infiéis. Dessa forma, a resistência islâmica na Palestina é descontextualizada e representada como sem uma causa política própria.Ao invés de um movimento autóctone é ora uma mera extensão da Irmandade Muçulmana ora um agente a serviço do Irã ou da Síria. De qualquer forma, é parte de uma conspiração mundial islâmica, o que o torna muito mais ameaçador e digno de ser combatido. No cerne dessa empresa de deslegitimar o Hamas está a sua carta, que é um documento chave da propaganda pró-Israel. A citação de tal fonte visa, sobretudo, “despalestinizar” o Movimento ao enfatizar seu caráter religioso e ofuscar sua natureza nacional. Ignora-se completamente que o partido tenha mudado consideravelmente desde sua fundação e que tal documento não tenha nenhuma ressonância no discurso de seus dirigentes atuais, legítimos representantes do nacionalismo palestino. Embora suas raízes remontem ao início da década de 1980 e a uma célula da Irmandade Muçulmana, o grupo de Gaza que originou o Hamas passou por um processo 
gradativo de "palestinização", separando-se do discurso panislâmico e se definindo com base no conceito de nação palestina (SIEFFERT, 2010, p. 59-60).

Em 2005, o movimento deu um passo considerável para sua politização. Passados os anos iniciais caracterizados pela intransigência, por atentados mortíferos e pela rejeição da Autoridade Palestina e dos acordos de Oslo, o Hamas optou por participar das eleições do Conselho Legislativo palestino, em janeiro de 2006. Na ocasião, publicou dois documentos, nos quais em grande parte ultrapassou sua dupla natureza, islâmica e nacionalista, em favor da segunda. O objetivo principal colocado é explicitamente "libertar a Palestina”, cabendo à religião um lugar secundário, e o Movimento vê favoravelmente o pluralismo e a alternância política. Em suma, “não sobra nada ou quase nada da carta de 1988”. Inclusive, Israel é implicitamente reconhecido, visto que o Movimento afirma buscar a criação de um Estado nas fronteiras anteriores a 1967. Mas, tal qual ocorrido com a OLP no final dos anos 1980 início dos 1990, a carta do Hamas continua a ser evocada para retardar o reconhecimento oficial do Movimento palestino como legitimo (SIEFFERT, 2010, p. 61-63).

Assim como Sieffert, Norman Finkelstein também aponta para as mudanças internas pelas quais passou o Hamas. Ele cita um estudo de uma agência governamental estadunidense, segundo o qual o Movimento tem dado repetidos sinais que está pronto para iniciar um processo de coexistência com Israel. Sua liderança política, Khalid Mishal, afirmou em março de 2008 que a maior parte das forças palestinas - incluindo o Hamas - aceitava um Estado nas fronteiras de 1967. Logo após a operação Chumbo Fundido, ele reiterou que o objetivo continuava ser constituir o Estado palestino com Jerusalém Oriental como capital, desmantelar os assentamentos ilegais e cumprir o direito de retorno dos refugiados palestinos - nada além do que as resoluções da ONU preveem. Segundo Finkelstein (2010, p. 45), a partir de meados dos anos 1990, o Hamas raramente mencionou sua carta notoriamente antissemita, "e agora não mais cita ou se refere a ela”. Mesmo antes do ataque à Gaza em 2008-2009, os oficiais israelenses sabiam que um acordo diplomático podia ser alcançado. Dessa forma, tanto para Finkelstein quanto para Sieffert, é justamente essa aceitação de Israel e da solução dos dois Estado pelo Hamas que coloca um grande desafio para o establishment israelense e torna necessária a supressão do Movimento, eliminando-o como um parceiro de negociação legítimo contrário aos termos estabelecidos no tendencioso "processo de paz", muito desfavoráveis aos palestinos (ARURI, 2006). Afinal, enquanto Oslo enraizou ainda mais a ocupação, “não levou, e não pode levar a lugar algum” (PAPPE, 2006, p. XVIII).

Finkelstein também observa que, quando o Hamas foi democraticamente eleito em janeiro de 2006, Israel e os Estados Unidos logo apertaram o cerco. Foi exigido do novo 
governo que renunciasse à violência e reconhecesse Israel, assim como os tratados anteriores assinados pela Autoridade Palestina. Contudo, conforme o autor, tais condições foram completamente unilaterais, pois não foi demandado de Israel a retirada dos territórios ocupados em 1967 e nem a aplicação do direito dos palestinos à autodeterminação. Se o Hamas deveria reconhecer Oslo e outros acordos - "que perpetuaram a ocupação e permitiram a Israel expandir em muito seus assentamentos ilegais -, tampouco foi exigido que Israel cumprisse com sua parte nos acordos, ficando livre para transgredi-los” (FINKELSTEIN, 2010, p. 27). Dessa forma, para os críticos, ao invés de um “ninho de terroristas” Gaza seria o reduto da luta anticolonial travada na Palestina.

\section{Gaza como laboratório}

Em um artigo publicado no Journal of Palestine Studies, Darryl Li (2006) defende que o desengajamento unilateral, juntamente com os “fechamentos”, as “zonas tampão” e o poder aéreo empregado por Israel em Gaza, seria um meio para alcançar os objetivos geográficos e demográficos do sionismo. Seguindo seus apontamentos, o território pode ser visto como um "laboratório", no qual Israel testa um balanço dúbio entre o máximo controle e a mínima responsabilidade, refinando técnicas que também são sugestivas para possíveis usos futuros na Cisjordânia. Ele sublinha que, de forma geral, tem havido duas formas de se analisar a Faixa, sendo ambas imprecisas. A primeira, ao enfocar os Territórios Ocupados ou a Questão Palestina como um todo acaba por desconsiderar suas particularidades. A segunda enfatiza sua excepcionalidade, evocando sua “desconcertante pobreza, sufocante aglomerado e letárgico isolamento”.

Para Li o mais adequado é olhar para Gaza e para a Cisjordânia como representantes de duas fases distintas do processo comum de segregação, confinamento e vigilância produzido pelo projeto sionista de judaizar a Palestina. Seu objetivo imediato para o território seria desenvolver um silencioso gerenciamento do conflito, dentro de níveis de violência aceitáveis, para garantir a legitimidade e o tempo necessário para avançar a colonização na Cisjordânia e nas zonas árabes dentro de Israel. O desengajamento seria o estágio mais avançado desse processo, até então testemunhado. Portanto, para Li, Gaza é um laboratório em pelo menos três sentidos interligados, ao invés de um "bantustão”, uma "bomba-relógio”, a "maior prisão a céu aberto" ou um "gueto". Primeiro, é um espaço no qual Israel testa e refina técnicas de gerenciamento, buscando equilibrar máximo controle sobre o território com mínima responsabilidade sobre sua população. Segundo, é um tipo de “solo de provas” para 
práticas passiveis de serem utilizadas na Cisjordânia, à medida que a vida dos palestinos lá se constitua em um arquipélago de "Faixas de Gaza isoladas" - fato que, segundo Li, vem acontecendo. Terceiro, tendo em vista que a Faixa representa um estágio de concentração e segregação sem precedentes, constitui-se no espaço mais próximo das "puras condições” de um laboratório, cujos experimentos - inclusive de armamentos - podem ser reproduzidos em qualquer outro lugar.

Na perspectiva de Li (2006), as experiências contínuas visando equilibrar controle máximo e responsabilidade mínima surgem e são modeladas pela necessidade do projeto sionista de superar determinadas restrições históricas, como a presença e a resistência de uma população nativa não-judaica no território disputado. Tais embates produziram um duradouro e bem conhecido mantra operacional, que guia as políticas sionistas de assentamento e anexação: “máximo de terras, mínimo de árabes”. Essa lógica é aplicável na política de anexação e colonização, responsável por uma transferência populacional que perdura até hoje - vide Jerusalém.

O aprimoramento do "sistema de controle" a distância, somado a violentas operações punitivas, faz com que os acontecimentos iniciais do século XXI na Faixa de Gaza denotem uma continuidade, e quiçá uma agudização, da barbárie que caracteriza os confrontos assimétricos nos Territórios Palestinos Ocupados. Esse refinamento das políticas de “gerenciamento populacional” em Gaza ocorre, visto que certas circunstâncias proibitivas impedem Israel de simplesmente empurrar os nativos para fora do território, como a existência de um sistema legal internacional que zela pelos direitos humanos e condena qualquer forma de desenraizamento populacional. Assim, do pressuposto "máximo de terras, mínimo de árabes” nasceu o corolário “máximo de árabes em um mínimo de território”. É nesse espaço de confinamento ou "territórios mínimos", que surge o desafio de conciliar controle e responsabilidade. Gaza seria a culminância dessa lógica, visto que sua área constitui meros $1,4 \%$ da Palestina ao passo que abriga cerca de $25 \%$ dos palestinos não exilados.

Como um laboratório, o território está isolado e sujeito a uma lógica de funcionamento própria. Para que esteja “mais próximo das puras condições de experimento” é determinante que seus gerenciadores gozem de uma relativa liberdade, estando desvencilhados de acordos e tratados que restrinjam seus testes (LI, 2006). Nessa ótica, de fato, Israel criou em Gazauma permanente exceção na lei (campo), conforme evidenciado por uma miríade de relatórios de entidades não governamentais e internacionais que denunciam a política israelense em relação à população local. 
Tudo que lá é cometido se justifica pela "guerra total” contra o Hamas ou como respostas às atitudes dos terroristas que operam no território. Assim como no Iraque e no Afeganistão, sob o signo da "guerra contra o terror” as mais diversas violações são cometidas. Central nesse processo são os assassinatos extrajudiciais e as prisões de membros da resistência palestina na Cisjordânia, que provocam o revide com misseis caseiros a partir de Gaza, que por sua vez legitimam a "necessidade” afirmada por Israel de manter sua segurança (SIEFFERT, 2010). Nessa dinâmica, tanto a mídia quanto os governos sionistas ignoram os apelos das guerrilhas palestinas para que Israel deixe de assassinar seus membros, e assim os disparos cessarão, e os ataques anteriores que, geralmente, são responsáveis pela retaliação com foguetes e rompimentos dos cessar-fogo, e não o contrário (ESPOSITO, M. 2006).

\section{Os palestinos de Gaza como homo sacer}

Aproximando-se da perspectiva de Darryl Li, outra possibilidade para se compreender teoricamente a realidade de Gaza, mais especificamente a impunidade generalizada e a morte banal de civis, é considerá-la com base nas reflexões do filósofo Giorgio Agamben sobre estado de exceção, campo e homo sacer.

Partindo desse referencial, o cerco e as diversas operações militares empreendidas contra a Faixa de Gaza, que têm resultado em uma destruição generalizada e na morte e no sofrimento indiscriminado de civis, inserem-se no quadro da política na modernidade, no qual cada vez mais o poder se apropria da vida nua, ou seja, da vida biológica e não política dos sujeitos, submetendo-a e tornando-a seu objeto. Cabe ao soberano a decisão sobre o valor ou o desvaler da vida como tal, que então pode ser mantida viva, deixada à mercê da morte ou sistematicamente aniquilada. Dessa forma, várias populações, dentre as quais estão os palestinos, ao mesmo tempo em que têm seus direitos assegurados por Estados ou por tratados ou ainda entidades internacionais, sofrem a suspensão na prática de tais direitos. Encontramse assim completamente expostos à soberania de Estados e de seus agentes e no limiar entre a exceção e a norma, entre a exclusão e a inclusão, podendo suas vidas ser retiradas sem que isso incida em uma violação (RUIZ, 2007).

Em outras palavras, se as sociedades modernas definiram a igualdade jurídica como um dos alicerces de suas instituições, ela é negada efetivamente por injustiças estruturais. Essa contradição entre igualdade formal e desigualdade real é evidente na vida (negada) dos excluídos sociais. Eles gozam, formalmente, de todos os direitos garantidos pelo Estado e por entidades internacionais. Contudo, na prática, seus direitos fundamentais a uma "vida 
digna”sofrem uma “suspensão real, gradual ou extrema”. Essa situação de inclusão excludente expõe a vida humana a uma flagrante contradição. Ao mesmo tempo que é protegida formalmente pelo direito, é negada pela suspensão prática dos direitos. A vida dos excluídos é assim uma exclusão inclusiva da vida. "Uma vida excluída pela suspensão dos direitos básicos para sua existência digna, porém incluída formalmente na ordem social e jurídica como vida normal”.

É uma vida paradoxal, normalizada no ato da exclusão e excluída sob a forma de suspensão normal dos direitos. A vida do excluído desvela as incongruências e insuficiências da igualdade formal do Estado de direito enquanto este normaliza a suspensão real dos direitos. Ela se encontra exposta no limite da vulnerabilidade e, nesse limite, desmascara as artimanhas das formalidades jurídicas do Estado de direito quando são utilizadas como artifícios legitimadores da exclusão, reduzindo a vida excluída à normalidade incluída na ordem (RUIZ, 2007, p. 29).

Essa contradição entre a igualdade formal e a desigualdade real da vida excluída significa, em primeiro lugar, uma suspensão de fato do direito à igualdade. A vida excluída se encontra diante de uma injustiça estrutural e no limite de sua sobrevivência. Ela sofre uma suspensão gradual ou extrema dos direitos fundamentais que a expõe, como vida vulnerável, a um sofrimento injusto, levando-a inclusive ao limiar da morte ou condenando-a a uma morte que poderia ser evitada. Esta estratégia exclui a vida humana incluindo sua vulnerabilidade, seu sofrimento e sua morte por inanição como fatos normais da dinâmica social (AGAMBEN, 2007).

O bloqueio e o isolamento da Faixa de Gaza, ainda que como experiências muito particulares, ilustram essa exclusão inclusiva da vida. Sua população se encontra na margem dos direitos internacionais e das obrigações de Israel como país ocupante e está submetida a privações, a um fechamento hermético e a ataques indiscriminados. Castor Bartolomé Ruiz, coordenador da cátedra da UNESCO de direitos humanos, sustenta essa perspectiva ao afirmar que os palestinos integram o grupo de populações que atualmente vive sob um estado de exceção. Em sua ótica os Territórios Palestinos Ocupados merecem uma atenção especial:

estes territórios são um autêntico paradoxo jurídico e um exemplo de controle biopolítico por parte do Estado de Israel. Neles as populações, sob a argumentação da potencial ameaça terrorista, são cercadas, vigiadas em seus movimentos de idas e vindas, controladas em todas as suas formas de subsistência, fiscalizadas em todos os seus movimentos. Os territórios palestinos constituem, atualmente, autênticos modelos de campos de exceção sobre os quais se aplica a soberania da força como método de controle. Como todo campo de concentração, seu objetivo final é o controle da 
população, evitar sua expansão e, provavelmente, promover uma política de diminuição étnica. Esta não pode ser chamada de extermínio porque não há um genocídio massivo; porém, sim, há uma morte seletiva de pessoas, uma dispersão estratégica das populações, um enclausuramento e fragmentação dos grupos populacionais, promovendo uma paulatina restrição de crescimento populacional (RUIZ, 2007, p. 29).

Ou seja, apesar da existência de princípios legais que fundamentam as relações entre Estados e destes com minorias submetidas a sua soberania, na prática as populações palestinas - mais explicitamente os habitantes de Gaza - se defrontam com a anulação de seus direitos formais. Malgrado as convenções internacionais, além do desrespeito israelense a direitos básicos como a liberdade e o acesso irrestrito a serviços fundamentais, a própria vida dos palestinos está desprotegida e é constantemente violada. O emprego amplo e irrestrito do conceito de "terrorista” para defini-los cumpre um papel central na criação dessa exclusão real, dado que torna sua morte e punições coletivas aceitáveis. Usando o conceito de Agamben (2007), os palestinos de Gaza se caracterizam pela vida nua diante de uma exceção soberana, ou seja, constituem a vida supérflua, desprotegida e exterminável, no sentido de que pode ser retirada impunemente por qualquer um sem que se cometa uma violação. Como homo sacer, os gazianos são matáveis, mas não sacrificáveis. Sua vida é retirada da forma mais crua, sem rituais ou procedimentos jurídicos. Assemelhando-se aos judeus na Alemanha nazista e aos militantes de esquerda na Argentina durante a ditadura, sua morte não culmina em uma transgressão, afinal seus direitos estão suspensos e sequer são reconhecidos como portadores de tal ou até - em casos mais extremos - de humanidade. Em suma, são aqueles que podem ser mortos impunemente.

É bem difundida na bibliografia crítica e nos relatórios de organizações não governamentais e da própria ONU a percepção de uma “cultura da impunidade” em relação às populações palestinas dos territórios ocupados, ou seja, dos delitos, incluindo o homicídio, que não resultam em condenação. Dos inúmeros casos disponíveis cabe citar somente alguns. Em seus artigos, o jornalista israelense Gideon Levy faz várias alusões à exposição nua da vida dos gazianos. Comentando o assassinato a sangue frio do palestino Yasser Temeizi, Levy (2010, p. 130) afirma que soldados das FDI o prenderam, espancaram-no e o mataram na frente de um de seus filhos sem razões. "Uma investigação que poderia ter sido completada em uma hora está sendo protelada interminavelmente. Nem um único palestino foi questionado, como de costume; nem um único soldado foi preso - e muito provavelmente nenhum será - como de costume”. Ele cita também o revelador depoimento de um soldado israelense: "É isso que é tão bom, por assim dizer, em Gaza: você vê uma pessoa na rua... e 
você pode simplesmente atirar nela” (2010, p. 142). Em um artigo de fevereiro de 2009, faz uma severa crítica aos juristas israelenses - "sempre prontos para manter o silêncio ou legitimar qualquer operação militar" - diante do "uso de fósforo branco no meio de centros populacionais, de "bombardeios indiscriminados” e dos “danos desproporcionais infligidos à população civil, aos comboios de suprimentos e às equipes médicas” durante a Chumbo Fundido. "O establishment judicial foi alistado - ou, para ser mais preciso, se alistou a si mesmo -, tendo uma participação na operação militar. As FDI sabiam o que seus soldados estavam fazendo em Gaza e não irão investigar nada com seriedade” (LEVY, 2010, p. 122$123 ; 141)$.

Em um relatório do Comitê Público Contra a Tortura em Israel (PCATI), escrito em parceria com o Centro Legal para os Direitos da Minoria Árabe em Israel (ADALAH), a situação dos Territórios Palestinos, no que tange ao desrespeito aos direitos humanos e à suspensão da lei, é comparada aos outros "locais sombrios” nos quais a "guerra contra o terror” está sendo travada, como Guantánamo. Todos esses espaços, inclusive Gaza,caracterizam-se por "buracos negros legais", que privam os detentos de seus direitos mais básicos. Tais transgressões são, para o PCATI, produto de uma política de punição coletiva contra toda a população de Gaza, desde o desengajamento, em 2005. Nos combates, além das violações aos direitos dos detidos, não há qualquer discernimento entre civis e combatentes (de ambas as partes) e uma “completa suspensão do estado de direito” (PCATI; ADALAH, 2010). Essa definição utilizada pelo PCATI e ADALAH está em consonância com o conceito de espaço de exceção em Agamben (2007, p. 171), que é o local no qual habita a vida nua, "uma zona de indeterminação na qual as palavras vida e morte perdem seu significado”, sendo ambas controladas pelo homem e por suas tecnologias e dependentes de uma decisão política soberana.

No livro do ativista-testemunho Hérnan Zin (2006, p.256; 279-280) também há diversos casos reveladores dessa "cultura da impunidade”, como "o massacre de Beit Hanun” e da família Galia, alvejada a partir de uma embarcação naval israelense, mas para este governo morta devido à explosão de uma mina enterrada na praia. Quanto ao ocorrido em BeitHanun - onde dezenove civis palestinos morreram e dezenas ficaram feridos -, segundo a Human Rights Watch (2006) o inquérito interno das FDI falhou na investigação das principais questões, como se o ataque violou a lei internacional e quem deve ser responsabilizado pelo fogo letal. Conforme a entidade referida, “a investigação deve examinar a política que tem levado Israel a disparar cerca de quinze mil tiros de artilharia em Gaza, desde setembro de 2005 [desengajamento]”. 
Em um press release, a renomada ONG B'Tselem afirma que três anos após a operação Chumbo Fundido não há como os militares israelenses sustentarem seus argumentos contra o estabelecimento de uma comissão independente para investigar os fatos. Eles “falharam completamente em investigar eles mesmos, tendo em vista as escolhas políticas e a conduta das forças no campo em casos particulares” e dezenas de investigações abertas de casos envolvendo danos contra civis ainda não apresentaram resultados.

O advogado geral do corpo militar criou uma névoa em torno delas [investigações], impedindo qualquer possibilidade de examinar sua eficácia. As respostas da corporação ao B’Tselem, combinadas com relatos da mídia, indicam que três acusações foram apresentadas contra soldados que tomaram parte na operação: por roubo de um cartão de crédito de um civil palestino, pelo uso de uma criança palestina de nove anos como escudo humano e por "homicídio culposo de uma pessoa anônima" [...] As investigações que foram abertas, conforme o conhecimento do B'Tselem, não abordaram a responsabilidade de comandantes de alta patente, ao invés, focaram a conduta individual de soldados. A opção israelense de investigar apenas incidentes isolados, e não a conduta militar como um todo ao longo da operação, é motivo de preocupação, pois pessoas responsáveis por violações extremamente graves do direito não tem sido questionadas (B'TSELEM, 2012. Tradução livre do autor).

Ou seja, apesar das diversas evidências de infrações aos direitos humanos e ao direito humanitário internacional, contidas em relatórios de organizações como a Anistia Internacional (2009), a Human Rights Watch (2009a; 2009b) e a própria ONU (2009), as investigações internas de Israel sobre o ocorrido em Gaza entre dezembro de 2008 e janeiro de 2009 indiciaram pouquíssimos envolvidos. Evidenciando ainda mais a impunidade generalizada que culmina na vida nua dos gazianos, em três situações durante a Chumbo Fundido que envolveram mortes de civis e destruição de suas propriedades foram adotadas somente ações disciplinares isoladas. Conforme Norman Finkelstein, as FDI prometeram uma investigação após soldados que participaram da operação terem prestado publicamente seus testemunhos das violações lá cometidas. Entretanto, o inquérito foi encerrado poucos dias após ser aberto, concluindo que as alegações de assassinatos e destruição eram apenas rumores. Uma investigação interna subsequente das FDI constatou que nenhum civil foi propositadamente vitimado (FINKELSTEIN, 2010, p. 93). É muito significativo nesse ponto o seguinte trecho de um comunicado de Hala Khoury, diretor da ONG israelense ADALAH, advogado e conferencista nas universidades de Haifa e TelAviv, para quem a Suprema Corte Israelense contribui na promoção de uma "cultura da impunidade”: 
durante quarenta anos de ocupação não somente o governo israelense tem sistematicamente falhado em cumprir com suas obrigações mais básicas, como um poder ocupante sob as leis humanitárias internacionais, para garantir o bem-estar e a segurança da população civil nos Territórios Palestinos Ocupados, mas ele também fomentou uma cultura de impunidade entre seus militares [...] Israel não cumpriu com suas obrigações legais no âmbito do Direito Humanitário Internacional e dos tratados de direitos humanos que seu governo ratificou. Essas obrigações incluem o dever de investigar para estabelecer a verdade e processar e punir adequadamente os responsáveis por eventos relacionados a mortes e ferimentos causados a várias centenas de civis não envolvidos nas hostilidades e que resultam do uso por Israel de força letal no policiamento e na aplicação da lei no contexto dos Territórios Palestinos Ocupados (KHOURY, 2007, p. 1-2. Tradução livre do autor).

Diversos relatórios do ADALAH vêm denunciando o tratamento legal diferenciado para os crimes cometidos contra a população palestina. A mesma posição presente na carta acima citada é repetida em publicações posteriores da entidade. Citando um documento de 2009, “desde o começo da ocupação em 1967, o sistema legal israelense tem falhado em prevenir a continuação de políticas e práticas ilegais nos Territórios Palestinos Ocupados que violam o direito internacional”.

Em um relatório de meados de 2005, cujo título por si já é muito sugestivo ("Promovendo a impunidade: o fracasso do exército israelense em investigar ações impróprias”), a Human Rights Watch também faz essa denúncia da conivência com os casos de violência contra árabes. Entre 2000 e 2004, enquanto milhares de civis palestinos não envolvidos nas hostilidades ficaram feridos e mais de mil e seiscentos foram mortos pelas forças israelenses - sendo pelo menos quinhentas crianças -, as FDI informaram que haviam investigado criminalmente apenas setenta e quatro casos de uso ilegal de força letal, ou seja, menos de cinco por cento das mortes civis, nos aproximadamente quatro anos da Segunda Intifada. O historiador francês Pierre Razoux corrobora tal visão, reforçando a não investigação dos crimes contra civis e a decorrente difusão da impunidade (2006, p. 466).

Cabe lembrar que, desde a deflagração da Segunda Intifada, Israel não abre mais inquéritos obrigatórios nos casos em que suas forças de ocupação matam ou ferem civis palestinos não envolvidos nos combates. Isso tem engendrado uma "cultura da impunidade”, que por sua vez encoraja violações subsequentes dos direitos dos palestinos (PALESTINE CENTER FOR HUMAN RIGHTS, 2009; B’TSELEM, 2010). Na compilação dos acontecimentos diários em Israel e nos territórios ocupados, publicada regularmente no Journal of Palestine Studies, há diversos relatos de transgressões e violência contra os palestinos, incluindo mulheres, idosos e crianças, com a participação ou conivências das 
Forças de Defesa de Israel (ESPOSITO, M. 2006). Desde a Segunda Intifada, a classificação da violência e das mortes como parte de um “conflito armado”as tornam não investigáveis em quase todos os casos. A renomada ONG israelense B’Tselem critica essa definição oficial,

que efetivamente garante imunidade aos soldados e oficiais, com o resultado de que soldados que matam palestinos que não tomam parte nas hostilidades quase nunca são responsabilizados por seus crimes. Ao agir dessa forma o exército falha em cumprir com suas obrigações de tomar todas as medidas cabíveis para reduzir danos a civis e com suas obrigações prescritas pelo direito internacional de investigar danos a civis. Então, o exército permite que seus soldados e oficiais violem a lei, encorajando uma atitude de "puxar o gatilho feliz”, e mostra profundo desprezo pela vida humana (B'TSELEM, 2010, p. 6. Tradução livre do autor).

Em um relatório no qual investiga a situação de inquéritos policiais presentes em delegacias israelenses na Cisjordânia, a ONG YeshDin (2011) também denuncia a discriminação nas investigações oficiais conforme a nacionalidade da vítima e a do réu. Retornando ao documento da Humans Right, a conclusão da entidade é a de que "as práticas e procedimentos investigativos do exército israelense não são imparciais, completos, ou oportunos” e "os militares raramente trouxeram os infratores à justiça”.

No centro do problema está um sistema que confia no próprio testemunho dos soldados como limite para determinar se investigações sérias são justificáveis. Ao invés de iniciar investigações imparciais em tais casos, as FDI confiam nos "esclarecimentos operacionais", "investigações de campo" ou "investigações militares". As frequentes discrepâncias entre, de um lado, os relatos das FDI sobre mortes e ferimentos de civis, e, de outro, evidências médicas, em vídeo e de testemunhos oculares, resulta em partes da prática das FDI de pedir para seus soldados "investigarem" outros soldados da mesma unidade ou comando, sem procurar e pesar depoimentos de testemunhas externas. Alegações parciais de soldados são consideradas imediatamente, no melhor dos casos atrasando e no pior encerrando uma investigação rápida e imparcial digna desse nome. As chamadas “investigações operacionais” podem servir a propósitos militares úteis, mas não constituem investigações propicias: são completamente inadequadas para determinar se há evidências de uma violação de direitos humanos ou do direito humanitário, e elas servem como pretexto para sustentar, incorretamente, que uma investigação teve lugar. Outra fraqueza crítica nesse sistema atual é a ausência do envolvimento da vítima no processo investigativo e a falha visível das FDI em solicitar ou considerar seriamente testemunhos das vítimas ou de pessoas não vinculadas às FDI como uma base para checar a confiabilidade dos relatos dos soldados (HUMAN RIGHTS WATCH, 2005, p. 4-5. Tradução livre do autor).

Ainda segundo esse relatório da Human Rights Watch, a novidade não é a impunidade sistemática, mas sua ampliação: 
essa crítica do sistema e de suas falhas não é nada nova. Diferentes aspectos da impunidade das forças de segurança israelenses nos Territórios Palestinos Ocupados têm sido veiculados em comissões e processos judiciais, artigos de jornais e nos encontros do Knesset por mais de vinte anos [...] Quando investigações de fato ocorrem, as mortes e os danos a palestinos são tratados com menos seriedade que outras infrações ou violações, e diferentemente dos casos nos quais os prejudicados pelas FDI são judeus israelenses. O que é novo é o crescente número de mortes e danos a civis que deveria, mas não tem as sérias investigações que merece. Todas as mortes e os ferimentos de civis no levante palestino de 1988-1993 foram investigados, embora a qualidade das investigações tenha sido frequentemente pobre. Com a eclosão dos conflitos em setembro de 2000, as FDI mudaram essa política, afirmando que as mortes de civis nos Territórios Palestinos Ocupados não mais seriam rotineiramente investigadas, pois a situação estava "se aproximando de um conflito armado" e as investigações seriam limitadas a “casos excepcionais” (HUMAN RIGHTS WATCH, 2005, p. 5. Tradução livre do autor).

Pensando teoricamente, a situação se clarifica ao considerarmos Israel como uma etnocracia (YIFTACHEL, 2006). Um Estado apropriado pelo grupo étnico majoritário que utiliza de suas instituições para fazer avançar seus interesses coletivos, sobretudo o controle sobre territórios disputados. Os “árabes israelenses” e os habitantes dos Territórios Ocupados se constituem no "outro" ameaçador e demonizado, que tem seus direitos cerceados e a conivência com sua transgressão garantida. Dessa forma, é possível compreender porque as vítimas não têm acesso aos procedimentos investigativos adotados e o sistema militar israelense não é independente e carece de investigações efetivas que culminem na responsabilização dos culpados, sendo ele, portanto, “opaco", "lento" e "receptivo à repressão” (INTERNATIONAL FEDERATION OF HUMAN RIGHTS, 2010). Em suma, à medida que “o sistema não proporciona a justiça, a verdade ou uma reparação significativa”, os palestinos e árabes israelenses, como homo sacer, ficam expostos nuamente à exceção soberana.

\section{Gaza como campo}

Se for possível pensar nos habitantes da Faixa como homo sacer - à medida que são extermináveis, matáveis, mas não sacrificáveis, ou que sua morte não se constitui em violação à lei -, também o é considerar o território como uma espécie de campo. Segundo Agamben (2007), este é o “paradigma oculto do espaço político da modernidade”, a localização visível e permanente do Estado de exceção, regida pela lei marcial ou pelo estado de sítio. 
Historicamente, o campo surge entre os séculos XIX e XX para concentrar insurretos, como foi o caso de cubanos e bôeres, nos conflitos respectivamente com espanhóis e ingleses. Em ambos os casos, tratou-se “da extensão, a uma inteira população civil, de um estado de exceção ligado a uma guerra colonial”.

O filósofo italiano destaca que os campos - cujos exemplos mais notórios são os modelos nazistas - não nascem do direito ordinário ou carcerário, mas “do estado de exceção e da lei marcial”. A base jurídica do internamento neles não é o direito comum, mas a schutzhaft ou custódia protetiva, que foi um estatuto jurídico utilizado durante a República de Weimar e o Terceiro Reich como uma “medida policial preventiva”. Ela permitia ““tomar sob custódia’ certos indivíduos independentemente de qualquer conduta penalmente relevante, unicamente com o fim de evitar um perigo para a segurança do Estado”. O fundamento jurídico da schutzhaft era a proclamação do estado de sítio ou do estado de exceção, com a correspondente suspensão dos direitos constitucionais garantidores das liberdades pessoais. Sob o regime nazista, o estado de exceção perdeu seu caráter interino e passou a se confundir com a própria norma (AGAMBEN, 2007, p. 174-177).

Agamben destaca que há um nexo constitutivo entre estado de exceção e campo de concentração. “O campo é o espaço que se abre quando o estado de exceção começa a tornarse a regra”. Como espaço de exceção permanente, é uma zona de indeterminação na qual a vida e a morte são completamente controladas e perdem seu significado como definição, recobrando-o somente a partir da decisão soberana. As fronteiras entre ambas são moveis e estão sujeitas à decisão soberana. Nos campos, o estado de exceção, que era essencialmente uma suspensão temporal do ordenamento com base numa situação factícia de perigo, adquire uma disposição espacial permanente que, como tal, permanece estavelmente fora do ordenamento normal.

Portanto, as populações reclusas, extermináveis como homo sacer, ficam sujeitas às situações mais extremas, dado que estão expostas aos representantes do poder soberano, privadas de qualquer direito ou mesmo do reconhecimento de sua humanidade. Em março de 1933, por meio da schutzaft, Himmler decidiu criar em Dachau um “campo de concentração” para prisioneiros políticos, sem relação com as regras do direito penal e do direito carcerário. O intuito foi justamente manter esses espaços "na mais completa indeterminação possível” e na absoluta independência de todo o controle e ordenamento judiciário. Ou seja, como a schutzaft não tinha nenhuma necessidade de se fundamentar juridicamente nas instituições e nas leis vigentes, os campos são um peculiar espaço de exceção (AGAMBEN, 2007, p. 174177). 
Como espaço de exceção, o campo tem um estatuto paradoxal. É um pedaço do território e não um espaço externo que é posto fora do ordenamento jurídico normal. Os reclusos nele são incluídos por meio da própria exclusão do ordenamento normal como exceção ou custódia preventiva. É o próprio estado de exceção que permite a captura no ordenamento e exclusão, tornando a norma indiscernível da exceção. “O campo é, digamos, a estrutura em que o estado de exceção, em cuja possível decisão se baseia o poder soberano, é realizado normalmente”. Em outras palavras, a exceção, antes decretada pelo soberano por um período temporário e com o fito de proteger o regulamento, é mantida indeterminadamente dado que o soberano produz a situação necessária e decide sobre ela. Como no campo não se discerne questão jurídica e factual, não faz sentido questionar a legalidade ou ilegalidade daquilo que nele sucede. “O campo é um híbrido de direito [como prerrogativa do soberano de decretar exceção] e de fato, no qual os dois termos tornaram-se indiscerníveis”. Tudo é possível nos campos, que constituem um espaço de exceção onde os direitos individuais são integralmente suspensos e as pessoas têm sua humanidade borrada. A vocação dos campos é realizar estavelmente a exceção.

Conforme Agamben, as atrocidades nos campos foram e são possíveis pela sua estrutura jurídico-política que deixa os detentos em uma zona de indistinção entre externo e interno, regra e exceção, lícito e ilícito, que anula os direitos subjetivos e de proteção jurídica. Os campos não são experiências exclusivamente pregressas, mas fatos inerentes à estrutura política da modernidade, estando presentes também nas democracias liberais. Devem ser vistos "não como um fato histórico e uma anomalia pertencente ao passado (mesmo que, eventualmente, ainda verificável), mas, de algum modo, como a matriz oculta, o nómos do espaço político em que ainda vivemos” (2007, p. 173). Em suma, se a essência do campo consiste na materialização do estado de exceção e na consequente criação de um espaço em que a vida nua e a norma entram em um limiar de indistinção, encontramo-nos diante de um toda vez que tal estrutura é criada. O filósofo define como campo tanto o velódromo de inverno no qual os judeus foram recolhidos pelas autoridades de Vichy antes de serem entregues aos alemães quanto o estádio de Bari, onde a polícia italiana concentrou provisoriamente os imigrantes clandestinos albaneses antes de os expelir para seu país, em 1991.

Aproximando essa definição de campo da situação de exceção exposta mais acima nos relatórios de ONGs, é possível pensar os Territórios Palestinos, em especial a Faixa de Gaza, por meio do conceito. Embora o governo oficial seja o Hamas, Israel controla o acesso ao território - pelo menos até a derrubada do regime de Mubarak no Egito o gerenciamento foi 
quase total - e constantemente intervém na forma de bombardeios precisos ou de operações terrestres. Ainda que tenha renunciado às suas obrigações sobre Gaza, o "Estado judeu" continua a manipular a vida de seus habitantes, submetendo-os a condições degradantes em contradição aos deveres dos ocupantes diante das populações submetidas. Ou seja, os direitos e a proteção legal que na teoria os gazianos gozam em sua relação com Israel, na prática estão suspensos há muito tempo, e com maior ênfase ainda a partir de 2005. Como os demais habitantes de campos, eles estão sujeitos a tudo, em um espaço onde o ordenamento normal que regula as relações ocupante-ocupadoe stá suspenso e a exceção é realizada estavelmente.

Quando no dia doze de setembro de 2005 Israel executou o desengajamento unilateral da Faixa, seu governo declarou o fim da administração militar sobre o território - iniciada em 1967 - e promulgou a entrada em vigor da cláusula treze do código criminal de 1977: seus residentes serão acusados de cometer crimes internacionais e para julgá-los em corte há a necessidade de consentimento escrito do Procurador-Geral. Três dias depois, Ariel Sharon declarava na Assembleia Geral da ONU “o fim do controle e da responsabilidade de Israel sobre a Faixa de Gaza”. Se no momento, o governo se absteve de formalizar o fim da ocupação,

em uma série de declarações feitas em hebraico ante a Suprema Corte de Israel expressou a posição de que o 'desengajamento' extingue as suas obrigações legais para com Gaza, deixando assim seu funcionamento e o cumprimento das obrigações, vis-à-vis seus residentes, responsabilidade exclusiva da Autoridade Palestina (GISHA, 2007, p. 8. Tradução livre do autor).

De acordo com a legislação internacional, esse mecanismo é inaceitável, à medida que Israel continuou a exercer a autoridade soberana, ao empreender invasões temporárias, mas frequentes, e controlar as fronteiras, o espaço aéreo, terrestre e marítimo, o acesso à água e à eletricidade, o registro da população, sua movimentação externa, a entrada de produtos e o sistema de taxas. À luz do direito internacional, a ONG Gisha e outras, como o PCATI e a ADALAH (2010), consideram que o território permanece sob ocupação e Israel é o Estado ocupante, e como tal está encarregado de cumprir uma série de leis específicas. Portanto, contrastando com a retórica governamental, o país não teria liquidado seu controle sobre Gaza e enquanto removeu alguns elementos como a presença constante de tropas terrestres reforçou outros significativos. Assim, ao invés de melhorar a situação da população, o desengajamento a colocou no limite entre a norma e a exceção e contribui para uma crise humanitária e econômica não vista em trinta e oito anos de controle israelense (GISHA, 2007, p. 8). 
Em seu relatório a Gisha busca justamente alertar a comunidade internacional da posição de Israel de negar a ocupação e das responsabilidades que ela impõe ao ocupante. $\mathrm{Na}$ perspectiva da entidade, Israel mudou suas leis domésticas considerando Gaza como um território estrangeiro, separado da Cisjordânia. Como não está sujeito ao seu controle por meio de presença militar constante, o país não teria nenhum dever diante dos gazianos. A Gisha rebate essa argumentação considerando, em consonância com as conclusões de Darryl $\mathrm{Li}$, que o avanço tecnológico dispensa a presença de tropas terrestres para efetivar o controle. Portanto, sendo um país ocupante Israel não estaria eximido de suas obrigações como tal. Um exemplo é o exercício de funções policiais em Gaza por meio de tecnologias de satélite e aviões não tripulados, que permitem identificar militantes suspeitos e matá-los instantaneamente (GISHA, 2007, p. 70-71).

O Relatório Goldstone também defende que Gaza se manteve como território ocupado, apesar do desengajamento. Ademais, questiona a capacidade de Israel proceder a uma “investigação genuína”, de uma forma “imparcial, independente rápida e efetiva”, ao sugerir que "o sistema geral de Israel apresenta características inerentemente discriminatórias, que dificultam em muito a busca por justiça da parte das vítimas palestinas” (UN FACT FINDING MISSION, 2009, p. 35; 73-74). Um relatório elaborado pela Amnistia Internacional sobre a mesma operação também destaca a parcialidade das investigações oficiais, que defendem que suas forças operaram de acordo com a legislação internacional e cometeram pouquíssimos e inevitáveis erros operacionais ou de inteligência. Conforme a entidade humanitária, as informações tornadas públicas por Israel se referem apenas a um "punhado" de casos e carecem de detalhes cruciais, somente repetindo afirmações feitas pelo exército e pelas autoridades desde os primeiros dias da operação sem, no entanto, apresentar evidências que sustentem suas alegações. Sequer as declarações oficiais buscam explicar a maioria das mortes civis em Gaza e a destruição massiva de propriedades civis. Citando o documento, "as afirmações do exército parecem mais uma tentativa de fugir de suas responsabilidades que um processo genuíno para estabelecer a verdade. Tal aproximação carece de credibilidade” (2009, p. 93). Cabe notar que, indo em direção completamente oposta ao relatório da ONU e de várias outras entidades, as publicações oficiais de Israel, feitas entre 2009 e 2010, negam qualquer responsabilidade pela destruição massiva de propriedades e, como esperado, afirmam que a grande maioria dos mortos e feridos em Gaza são terroristas (PALESTINE CENTER FOR HUMAN RIGHTS, 2009, p. 268). 


\section{Conclusão}

Tendo em vista o conceito de campo, o subterfúgio do governo israelense de negar a responsabilidade sobre a população de Gaza acentuou ainda mais o caráter de espaço de exceção do território, visto que, ao decretar o final da ocupação quando de fato ela permaneceu, afastou sua população do ordenamento legal e a tornou mais sujeita a um tratamento de exceção - homo sacer. Ou seja, ao passo que o desengajamento não retirou suas obrigações como poder ocupante em relação aos residentes de Gaza, internamente seu governo anunciou o final de sua responsabilidade, colocando a população referida em uma situação de exceção. Um exemplo é a argumentação empregada pelo Estado a fim de justificar os voos supersônicos executados para aterrorizar a população local durante a operação Primeira Chuva (2005): as leis de ocupação segundo as quais o ocupante tem obrigações legais de proteger as pessoas viventes nos territórios ocupados só são válidas quando estes estão sob uma autoridade estabelecida e passível de ser exercida pelo inimigo. Em síntese, valendo-se dos termos empregados pelo Centro Legal para a Liberdade de Movimentação (GISHA, 2007), enquanto buscou se destituir de suas responsabilidades o país continuou a controlar Gaza por meio de uma "mão invisível” - contudo, desprovido de responsabilidade, o que também é a tese de Darryl Li (2006).

No dia dezenove de setembro de 2007, Israel designou a Faixa como um "território hostil”, anunciando que sua responsabilidade sobre o território seria ainda mais reduzida, estando o país limitado a permitir somente a entrada de produtos estritamente necessários para evitar uma crise humanitária. O recrudescimento das sanções contra Gaza culminou na restrição ainda maior ao fornecimento de combustível, eletricidade, entrada e saída de pessoas e produtos e crescente monitoramento dos fundos. Segundo um alto oficial do governo, o intento era cortar a eletricidade e fechar as passagens em resposta a cada foguete lançado (o que se constitui em uma punição coletiva) e comprometer ainda mais a capacidade do Hamas de governar Gaza, à medida que as condições de vida são deterioradas (ISSACHAROFF; RAVID; SHAMIR, 2007).

Assim, também em Gaza, como nos demais campos, seres humanos foram e ainda são privados de direitos e prerrogativas protetoras, até o ponto em que cometer contra eles qualquer ato não constitui um delito. Eles foram transformados em mera vida nua, pois colocados no limiar entre fato e direito, entre norma e aplicação, entre exceção e regra. Reclusos, sua vida pode ser morta sem que se cometa homicídio. Isolados, com o seu estatuto político normal suspenso, estão em uma situação extraterritorial, abandonados, em estado de 
exceção, às mais extremas condições e experimentos. Recordemos Castor Bartolomé, segundo o qual “os territórios palestinos constituem, atualmente, autênticos modelos de campos de exceção sobre os quais se aplica a soberania da força como método de controle”.

Como uma população nua e exposta à morte violenta - excluída do direito formal constituído - os gazianos exacerbam as contradições e as “zonas de sombra” da etnocracia israelense, e a Faixa se apresenta como um espaço de constante manifestação da exceção soberana do “ocupante a distância”. É um território no qual o poder soberano israelense exerce o princípio da exceção, marginalizando sua população e suspendendo seus direitos fundamentais. Tudo isso justificado pela luta contra o terror palestino, ou a versão local da alQaeda.

\title{
NEW WARSAW, OCCUPATION LAB OR NEST OF TERRORISTS?: The Gaza Strip and the bare life
}

\begin{abstract}
Since 2005, when Israeli government withdrew its settlers and military from the Gaza Strip, the Palestinian territory was increasingly isolated and surrounded and their inhabitants subjected to collective punishment and violent death. The Israeli security policy regarding the Strip, officially adopted to curb Palestinian terrorism, has culminated in a long-suffering for the local population as a whole, who see their living conditions deteriorate to the extent that there is an overall deprivation of goods and services basic. Removing the simplifying official discourse of the war on terror, in this context in which violence was even more commonplace, we seeks to analyze the relevance of thinking Gaza from concepts who consider politics in modernity, as imunitas, field and homo sacer. The article summarizes these concepts by checking, based on testimonies and reports of nongovernmental organizations, their contribution to the understanding of the particular case.
\end{abstract}

Keywords: Occupied Palestinian Territories. Culture of Impunity. Israel. Homo Sacer. Unilateral Disengagement.

\section{Referências}

ADALAH.Statement to the UN Human Rights Council delivered by Adalah attorney Fatmeh El-'Ajou. ADALAH web site, 2009. Disponível em:

$<$ http://www.adalah.org/features/gaza/fatmeh\%20speech\%20hr\%20council.pdf > . Acesso em: 13 abr. 2011.

AGAMBEN, Giorgio. Homo Sacer: o poder soberano e a vida nua. Belo Horizonte: Editora UFMG, 2007.

ARONSON, George. Issues arising from the implementation of Israel's disengagement from the Gaza Strip. JournalofPalestineStudies, 2005, vol. 34, nº 4. Disponível em:

$<$ http://www.palestine-studies.org/files/pdf/jps/6517.pdf>. Acesso em: 20 abr. 2011. 
ARURI, Nasser H. El mediador deshonesto: el rol de EE.UU. en Israel y Palestina. Buenos Aires: Editorial Canaán, 2006.

B’TSELEM. Human Rights in the Occupied Territories. Annual Report 2007. Disponível em: $<$ http://www.btselem.org/Download/200712_Annual_Report_eng.pdf $>$. Acesso em: 23 mar. 2011.

. Void of responsibility. Israel military policy not to investigate killingsof Palestinians by soldiers. B'Tselem web site, out. 2010. Disponível em: $<$ http://www.btselem.org/download/201009_void_of_responsibility_eng.pdf>. Acesso em: 5 abr. 2011.

. Operation Cast Lead, three years on: Abject failure of the military's internal investigation mechanism. B'Tselem web site, 18 jan. 2012. Disponível em: <http://www.btselem.org/20120119_operation_cast_lead_3_years_on>. Acesso em: 10 mar. 2012.

BAUMAN, Zygmunt. Modernidade e holocausto. Rio de Janeiro: Jorge Zahar Ed., 1998.

ENRIQUEZ, Eugène. Matar sem remorso: reflexões sobre os assassinatos coletivos. História: Questões \& Debates. Os lugares da violência. V. 18, n. 35. Curitiba: Editora da UFPR, julho/dezembro de 2001.

ESPOSITO, Michele K. Chronology, 16 August - 15 November, 2005. Journal of Palestine Studies, vol. XXXV, ${ }^{\circ}$ 2, 2006. Disponível em: <http://www.palestinestudies.org/files/pdf/jps/6661.pdf>. Acesso em: 20 abr. 2011.

ESPOSITO, Roberto. Communitas: origen y destino de la comunidad. Buenos Aires: Amorrortu, 2003.

Immunitas: protección y negación de la vida. Buenos Aires: Amorrortu, 2005.

FEIERSTEIN, Daniel. El genocidio como práctica social: entre el nazismo y la experiencia argentina. $2^{\mathrm{a}}$ edição. Buenos Aires: Fondo de CulturaEconómica, 2011.

FINKELSTEIN, Norman G. This time we went too far. Truth and consequences of the Gaza invasion. New York: Or books, 2010.

GISHA. Disengaged occupiers: the legal status of Gaza. 2007. p. 8. Disponível em: <http://www.gisha.org/UserFiles/File/Report\%20for\%20the\%20website.pdf >. Acesso em: 9 mar. 2012.

GORDON, Neve. Israel’s occupation. Los Angeles: University of California Press, 2008.

HOBSBAWM, E. J. Sobre a história. São Paulo: Companhia das Letras, 1998.

HUMAN RIGHTS WATCH. Promoting impunity: the Israeli military's failure to investigate wrong doing. Human Rights Watch web site, vol. 17, nº 7, jun. 2005. Disponível em: <http://www.hrw.org/reports/2005/iopt0605/iopt0605text.pdf>. Acesso em: 13 maio 2011. 
HRW: IDF probe no substitute for real investigation. The Eletronic Intifada, 10 nov. 2006. Disponível em: < http://electronicintifada.net/content/hrw-idf-probe-no-substitute-realinvestigation/2926>. Acesso em: 10 mar. 2012.

Precisely wrong. Gaza civilians killed by Israeli drone-launched missiles.2009a.

Disponível em: <http://www.hrw.org/en/reports/2009/06/30/precisely-wrong-0>. Acesso em: 17 abr. 2011.

“I lost everything”. Israel’s unlawful destruction of property.2009b. Disponível em: $<$ http://www.afopa.com.au/storage/news-media/articles-reportsjournals/I\%20Lost\%20Everything\%20May\%202010.pdf>. Acesso em: 17 abr. 2011.

INTERNATIONAL FEDERATION OF HUMAN RIGHTS. Gaza: accountability - impunity. FIDH web site, 20 jan. 2010. Disponível em: <http://www.fidh.org/GAZA-AccountabilityImpunity>. Acesso em: 14 maio 2011.

INTERNATIONAL AMNESTY. Israel/Gaza. Operation 'Cast Lead': 22 days of death and destruction. 2009. Disponível em:

<http://www.amnesty.org/en/library/info/MDE15/015/2009>. Acesso em: 05 abr. 2011.

ISRAEL MINISTRY OF FOREIGN AFFAIRS. Behind the Headlines: Doha Agreement between Hamas and Fatah - A barrier to peace. MFA web site, 8 fev. 2012. Disponível em: $<$ http://www.mfa.gov.il/MFA/About+the+Ministry/Behind+the+Headlines/Doha_Agreement _Hamas_and_Fatah_Feb_2012.htm>. Acesso em: 17 mar. 2012.

The Hamas terror war against Israel. MFA web site, mar. 2011. Disponível em: $<$ http://www.mfa.gov.il/MFA/Terrorism-

+Obstacle+to+Peace/Hamas+war+against+Israel/Missile+fire+from+Gaza+on+Israeli+civilia n+targets+Aug+2007.htm>. Acesso em: 27 mar. 2012.

ISSACHAROFF, Avi; RAVID, Barack; SHAMIR, Shlomo. Cabinetdeclares Gaza 'hostileterritory'. Haaretz, 20 set. 2007. Disponível em: <http://www.haaretz.com/printedition/news/cabinet-declares-gaza-hostile-territory-1.229665>. Acesso em: 11 mar. 2012.

KHOURY-BISHARAT, Hala.Israel and the culture of impunity.Adalah's newsletter, vol. 37, jun. 2007. Disponível em: <http://www.adalah.org/newsletter/eng/jun07/ar1.pdf>. Acesso em: 11 maio 2011.

KLEIN, Menachem. The shift: Israel-Palestine from border struggle to ethnic conflict. New York: Columbia University Press, 2010.

LEVY, Gideon. The IDF's shooting range. Haaretz, 15 fev. 2004. Disponível em: $<$ http://www.haaretz.com/print-edition/opinion/the-idf-s-shooting-range-1.114011>. Acesso em: 17 mar. 2012.

. The punishment of Gaza. Londres: Verso, 2010.

LI, Darryl. The Gaza Strip as laboratory: notes in the wake of disengagement. Journal of Palestine Studies, 2006, vol. 35, nº 2.Disponível em: 
<http://www.pchrgaza.org/Library/darryl.pdf>. Acesso em: 13 maio 2011.

MAOZ, Zeev. Defending the Holy Land: a critical analysis of Israel's security \&foreing policy. Michigan: The University of Michigan Press; Ann Arbor, 2006.

NAFFA, Hisham. The palestinians in Israel and operation Cast Lead: a view from Haifa. Journal of Palestine Studies, 2009, vol. 38, n 3. Disponível em: <http://www.palestinestudies.org/files/pdf/jps/10332.pdf>. Acesso em 13 maio 2011.

NANCY, Jean-Luc. Conloquium. In: ESPOSITO, Roberto. Communitas: origen y destino de la comunidad. Buenos Aires: Amorrortu, 2003.

PALESTINE CENTER FOR HUMAN RIGHTS. Le PCHR condam neles tentatives israéli enn esvisant à légitimer les crimes commis à Gaza età proteger ceuxquis'em son trendus coupables de pour suítes judiciaires. In: REPORTERS SANS FRONTIERES. Gaza, le livre noir. Paris: Éditions La Découverte, 2009.

PAPPÉ, Ilan. The ethnic cleansing of Palestine. Oxford: Oneworld Publications Limited, 2006.

PAPPÉ, Ilan. Israel's message. London Review of Books, publicado em quatorze de janeiro de 2009. Disponível em: <http://www.lrb.co.uk/2009/01/14/ilan-pappe/israels-message>. Acesso em: 25 jan. 2012.

PCATI; ADALAH. Exposed: The treatment of Palestinian detainees during operation Cast Lead. 2010. Disponível em: <http://www.stoptorture.org.il/files/ExposedTreatment\%20of\%20Detainees\%20Cast\%20Lead_June\%202010.pdf >. Acesso em: 11 abr. 2012.

RABKIN, Yakov M. Judeus contra judeus: a história da oposição judaica ao sionismo. Tradução: Míriam Xavier de Oliveira. Cotia: Acatu, 2009.

RAMÍREZ, Roberto. Palestina: 60 años de limpieza étnica. Buenos Aires: Antídoto, 2009.

RAZOUX, Pierre. Tsahal: nouvelle histoire de l’armée israélienne. Paris: Perrin, 2006.

RUIZ, Castor B. As estratégias do (bio) poder na inclusão/excludente da vida humana. In: Revista Ethica. Rio de Janeiro, v. 14, n. 2, p. 11-39, 2007. p. 29. Disponível em: <http://www.revistaethica.com.br/v14n2Artigo1.pdf>. Acesso em: 23 mar. 2011.

UN FACT FINDING MISSION. Human Rights Council.Report of the United Nations FactFinding Mission on the Gaza Conflict. Geneva: [s.n.], 2009b. Disponível em: $<$ http://www2.ohchr.org/english/bodies/hrcouncil/docs/12session/A-HRC-12-48.pdf>. Acesso em: 29 mar. 2011.

YESH DIN. Law enforcement upon Israeli civilians in the West Bank.YeshDin web site, 16 fev. 2011. Disponível em: <http://www.yeshdin.org/userfiles/file/datasheets/YESH\%20DIN_Law\%20Enforcement\%20Monitoring\%20En g_2011.pdf>. Acesso em: 13 maio 2011. 
YIFTACHEL, O. Ethnocracy: land and identity politics in Israel/Palestine. Philadelphia: University of Pennsylvania Press, 2006.

ZIN, H. Llueve sobre Gaza. Vida y muerte en tierra sitiada. Buenos Aires: Ediciones B, 2007.

Recebido em: 31/03/2012

Aprovado em: 02/05/2012 